\title{
ENGLISH SPEAKING TEACHING METHODS FOR ELEMENTARY SCHOOL STUDENT AT KAMPUNG INGGRIS PONTIANAK
}

\author{
${ }^{1}$ Viqri Rahmad Satria* \\ ${ }^{1}$ Universitas Islam Negeri Maulana Malik Ibrahim Malang, Indonesia \\ *Corresponding Author: viqrirahmatsatria1@gmail.com
}

\begin{abstract}
This research aims to know speaking teaching methods used at Kampung Inggris Pontianak for elementary school student and tutor obstacles during teaching activity. The method applied in this research was qualitative approach with descriptive analysis. The data were collected from interview and observation with the owner of Kampung Inggris Pontianak, West Kalimantan. It was found that English speaking skill to elementary school students was separated into four levels; basic, intermediate 1, intermediate 2, and advanced. There are five methods applied by Kampung Inggris Pontianak to improve students English speaking skill. Flash card, watching movie, listening, games, and singing. There were two kinds of obstacle that tutors face during the class. First, most of the tutors' backgrounds were non-educational. So, they found it hard, sometimes, to control their elementary students who are very energetic. They might have English language competence. However, it is not adequate as their only competence to teach students compared to tutors with English educational background. Therefore, Kampung Inggris Pontianak holds micro-teaching practices to see tutor candidate performances before coming into class. Second, new students made many false answers on the placement test just to make them get into a lower level class than they are supposed to be. The researcher hopes this research will give knowledge to the reader of how tutors in Kampung Inggris Pontianak teaches speaking skills to their students.
\end{abstract}

Keywords: Kampung Inggris; Method; Speakin; Teaching

\begin{abstract}
ABSTRAK
Penelitian ini bertujuan untuk mengetahui metode pengajaran speaking yang digunakan di Kampung Inggris Pontianak untuk siswa sekolah dasar dan kendala tutor selama kegiatan mengajar. Metode yang digunakan dalam penelitian ini adalah pendekatan kualitatif dengan analisis deskriptif. Pengumpulan data dilakukan melalui wawancara dan observasi yang dilakukan di Pontianak, Kalimantan Barat. Berdasarkan temuan data diketahui bahwa Kampung Inggris Pontianak memfokuskan keterampilan berbicara bahasa Inggris pada siswa sekolah dasar yang terbagi menjadi empat tingkatan; dasar, menengah 1, menengah 2, dan lanjutan. Ada lima metode yang diberikan oleh Kampung Inggris Pontianak untuk meningkatkan kemampuan berbahasa Inggris murid. Flash car, menonton film, mendengarkan, permainan, dan bernyanyi. Ada dua macam kendala yang dihadapi tutor selama pelajaran berlangsung. Pertama, sebagian besar pengajar berlatar belakang non-keguruan. Hal itu membuat mereka terkadang kesulitan untuk mengontrol siswa SD yang sangat energik. Lebih lanjut, meskipun mereka mungkin berlatar belakang jurusan bahasa Inggris, namun hal itu tidak cukup untuk mengajar siswa dibandingkan dengan tutor dari latar belakang bahasa Inggris keguruan. Oleh karena itu, Kampung Inggris Pontianak mengadakan micro teaching untuk melihat sejauh mana para calon tutor dapat mengajar sebelum masuk ke kelas. Kedua, murid baru membuat banyak jawaban yang salah pada tes penempatan hal itu membuat mereka masuk ke kelas yang lebih rendah dari yang seharusnya. Peneliti berharap penelitian ini dapat memberikan pengetahuan kepada pembaca tentang bagaimana para tutor di Kampung Inggris Pontianak mengajarkan kemampuan berbicara kepada muridnya.
\end{abstract}


Satria, V.R. (2020). English Speaking Teaching Methods for Elementary School Student at Kampung Inggris Pontianak. Celtic: A Journal of Culture, English Language Teaching, Literature, \& Linguistics, 7(2), 183-190.

Kata Kunci: Bicara; Kampung Inggris; Metode; Pengajaran

\section{INTRODUCTION}

Pare English Camp, also famously known as Kampung Inggris Pare, has its own history that cannot be separated from the history of its founder, Kalend Osen. Mr. Kalend established the first English course namely BEC (Basic English Course) with its first six students on June 15, 1977 at Tulungrejo Village (Panduankampunginggris.com, 2019). Until now, many people come to Kampung Inggris Pare to upgrade their English skills, not only from Indonesia but also overseas like Malaysia, Thailand, Timor Leste, and Saudi Arabia (Nurjaya, 2018). Moazzam Malik, British Ambassador to IndonesiaTimor Leste-ASEAN (2019) states, Kampung Inggris Pare is one of the largest language centers in the world.

The large number of students with their good English skills is an indicator of the good quality of Kampung Inggris Pare. This makes people put their beliefs of studying English there. Unfortunately, because of the financial reason, many people wonder ask whether Kampung Inggris Pare has other branches in different regions, so English learners have another alternative not to go to Kampung Inggris Pare directly for their English improvement. The answer is Kampung Inggris Pare is only in Tulungrejo, Pare. If there is in another region, it is probably established by its alumni (Kampunginggris.com, 2019), like Kampung Inggris Jogja, Bandung, and Pontianak.

Kampung Inggris Pontianak is one of the courses in Indonesia which uses Kampung Inggris name and methods. Kampung Inggris Pontianak was established on March 10, 2017 by one of the Kampung Inggris Pare alumni, Syarif Ilham Zultami. Kampung Inggris Pontianak has had 20 tutors and 120 students in 2 different locations, Jl. Husen Hamzah and Jl. Tanjung Raya 2, Pontianak, West Kalimantan (Interview, 2020).

Although Kampung Inggris Pontianak applies most of Kampung Inggris Pare methods, Kampung Inggris Pontianak also adjust its teaching methods relevant to Pontianak citizens style of learning which more informal. Ramadhani \& Poedjieastutie (2020), stated that although learning system is likely similar between two or more cultures, there must be any differences. As culture is an integral part of language learning, the approach towards culture must be varied (Warschauer, 2000). Even though Java and Kalimantan are in the same country, Indonesia, it is possible to have any different academic system between both of them. It is all done to provide a solution to learners who are interested in experiencing study at Kampung Inggris Pare without having to go there (Interview, 2020).

Kampung Inggris Pontianak does not only implement Kampung Inggris Pare teaching methodology. To make it one step ahead, it also implements international schools learning ideas theoretically. One of the main program at Kampung Inggris Pontianak is on the level of elementary school. The program is how elementary school students are able to speak English fluently (Interview, 2020). This, of course, has its own challenge for tutors to make an effective teaching process and easy to understand.

Kampung Inggris Pontianak provides speaking program for elementary school students. According to Leong \& Ahmadi (2017), speaking is to say words orally, having communication as by talking, making request, and making a speech. Another definition is, according to Chaney (1998), speaking is the process of making and sharing meaning, 
Celtic: A Journal of Culture, English Language Teaching, Literature and Linguistics

Vol. 7, No. 2, December 2020.

E-ISSN: 2621-9158 P-ISSN:2356-0401

http://ejournal.umm.ac.id/index.php/celtic/index

verbal and non-verbal symbols in different context. According to Hornby (2005), speaking is a way of communication through oral between two people.

Human is programmed to be able to speak before able to read and write. Human being spends much more time to interact through oral rather than writing. It means, speaking is a very important skill because it is needed to have a conversation (Leong \& Ahmadi, 2017). Every language has its own speaking difficulties, English as well. However, speaking is very fundamental language ability to be mastered by English foreign students in order to reach the purpose of communication. It is very crucial to have speaking skill remembering that English is the international language. With speaking skill, we are able to communicate and interact with people in international scale (Garg \& Gautama, 2015, as cited in Setyowati, 2019).

According to the facts above, the researcher is interested to analyze English speaking teaching methods that are used for elementary school student at Kampung Inggris Pontianak. The researcher chose Kampung Inggris Pontianak because its name is similar with Kampung Inggris Pare. The problems analyzed include:

1. What teaching methods do the tutors apply when teaching English speaking for elementary school students?

2. What obstacles do the tutors face during teaching activity?

Similar research has been done previously. First, the research that has been done by Trisnadewi \& Lestari (Trisnadewi \& Lestari, 2018), namely "Pengaruh Language Games Terhadap Kemampuan Berbicara Bahasa Inggris". The subject of the research is 19 students of Z class in STMIK STIKOM Indonesia. The result of the research shows that language games can give positive and significant impact to the students' English speaking skill. Second, the research that has been done by Setyarini (Setyarini, 2010), namely "'Puppet Show": Inovasi Metode Pengajaran Bahasa Inggris Dalam Upaya Meningkatkan Kemampuan Berbicara Siswa SD". The result of the research shows that Puppet show is an innovative strategy. It can be seen through the final score after the students were given the action. Third, the research done by Nanda, et al (Nanda, et al, 2020), namely "Pengaruh Metode Pembelajaran Flash Card Terhadap Keterampilan Berbicara Bahasa Inggris Pada Siswa Sekolah Dasar". The data were collected from 18 third grade students of elementary school. The result of the research shows that the use of flash card in the experimental group is not significant.

Although similar research has been done before, this research has its own characteristics and differences. First, the data were collected from a course, not a school. Second, this research does not just analyze one particular method, but try to figure out several methods that are used at Kampung Inggris Pontianak. Third, this research also tries to figure out tutor obstacles during the class. That is, the researcher hopes this research is able to fulfill the previous research gap. The researcher hopes this research will give new knowledge to the reader.

\section{METHOD}

The method applies in this research is qualitative approach with descriptive analysis. Qualitative approach with descriptive analysis is used to deepen the data explanation. The data were from interview with the owner of Kampung Inggris Pontianak and observation done on August 10, 2020. The interview and observation were taken place at Kampung Inggris Pontianak on Jl. Husen Hamzah only once. The 
researcher did the interview and observation to obtain the data as complete as possible. Sampling technique used in this research is purposive sampling. Purposive sampling, also called judgement sampling, is a technique of choosing a particular participant because of the qualities the participant has. It is an intentional technique which does not have to rely on theories or a set number of participants (Etikan, 2015).

\section{FINDINGS AND DISCUSSION}

Tutor holds very important role to the children's English speaking skill. Therefore, at Kampung Inggris Pontianak tutor needs to have adequate capability for speaking and teaching. According to the recruitment, there are three categories of tutor:

1. Tutor who is graduated from Kampung Inggris Pontianak itself

2. Tutor from non-Kampung Inggris Pontianak alumni

3. Alumni of Kampung Inggris Pare

The percentage for tutor category number one is about $50 \%$. Meanwhile, category number two is $30 \%$. Last, for tutor category number three is about $20 \%$.

Kampung Inggris Pontianak also monitors its tutors through sharing session. Sharing session is done by the chief and the tutor himself, it is meant to understand and to look for way out if there is a problem faced by the tutor during the class. Through sharing session, Kampung Inggris Pontianak hopes that tutor gives the best effort to the children comprehension.

\section{English Speaking Class Placement}

Kampung Inggris Pontianak separates elementary school students into few levels based on their skills. Here the researcher provides the data of the elementary school student placement based on their speaking skill through diagram;

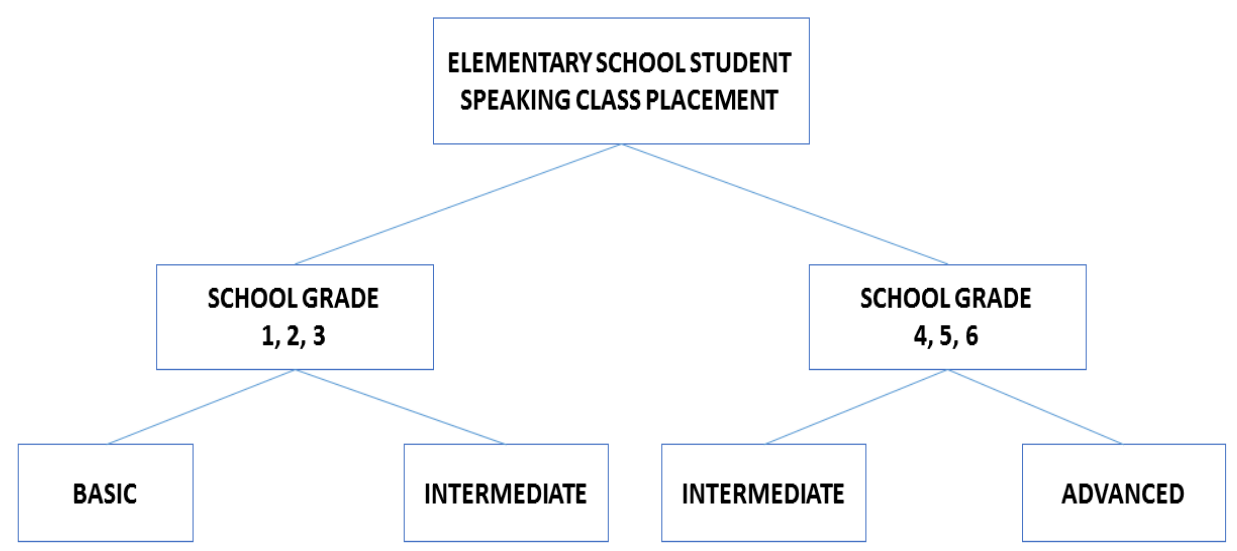

Figure 1. Speaking Class Placement for Elementary School Students

Students from grade one to three are separated into two levels, basic and intermediate. For students on grade four to six are separated into two levels as well, intermediate and advanced. Overall, there are four levels of speaking class at Kampung 
Inggris Pontianak which are separated into two big classes based on their grade at school.

The way for upgrading students level is based on the recommendation from the tutor. For example, after finishing basic level, if students have enough skill to be on intermediate level, tutor would recommend them to upgrade their level. It means that placement test is only done once if students have never come to Kampung Inggris Pontianak before.

\section{English Speaking Teaching Methods}

Motivation is important to students. Therefore, tutor needs to deliver materials within methods that students like. Kampung Inggris Pontianak applies few methods for teaching activity;

Table 1. Speaking Teaching Methods

\begin{tabular}{lc}
\hline No. & METHOD \\
\hline $\mathbf{1}$ & Flash Card \\
$\mathbf{2}$ & Watching Movie \\
$\mathbf{3}$ & Listening \\
$\mathbf{4}$ & Games \\
$\mathbf{5}$ & Singing \\
\hline
\end{tabular}

Flash card is the basic method used at Kampung Inggris Pontianak. Flash card is applied to enrich students vocabulary. Tutor guides students to comprehend the material. Students are given with basic vocabulary and asked to remember them. After given with some vocabulary, students are asked to guess the name of the object on the flashcard. According to Widowati \& Kurniasih (2018), to master active language skills, a person needs to be able to know passive skills. In other words, someone have to read before speak. The common basic problem is sometimes the students pronounce the name of the object with incorrect pronunciation and the tutor will try to fix it. However, even though students' error are common and natural event especially in the language classroom, the tutors are expected to correct the errors. It means, the tutors have to analyze which error should be corrected and how the teachers are able to help the students to make the errors work for them (Muhsin, 2016). Finally, if the students are able to answer the question given by the tutor, this becomes a good indicator of the student's progress of learning English.

The second method is watching movie, this method is used to make students understand how and what situation a particular topic of conversation happens. Through visual examples the students will be easier to practice their speaking activity. Another benefit of using this method is the students are able to practice their listening skill as well. As Heinic, et al. (Heinic, et al., 1996, as cited in Aryana \& Apsari, 2018) stated 
that there are some media which can be used to teach listening skill; the first media is sound system, however, sound system only provides audio to support listening practice. Another media is computer, computer provides DVD/MP3 record, it means that computer is able to provide audio along with video conversation that can support the students' activity to practice their listening skill. Therefore, watching movie can be beneficial to practice listening skill as the supporting skill to have good speaking skill. Furthermore, the students are expected to understand the whole story of the movie. If the students find difficulties or new vocabulary, they are asked to write the obstacles on a piece of paper. After watching the movie, the tutor will ask the students what the movie was about and continued with discussing the difficulties or new vocabulary. There are three goals that tutors can use as the indicator for their teaching using video/movie materials; first, is to facilitate the development of students' listening and speaking skills. Second, to cultivate students' competence of intercultural communications. Third, to cultivate students' aesthetic values and skill to appreciate English visual products of artistic values (Wang,2015).

The third method is listening, students are asked to listen English song or audio to improve their conversation capability. By understanding the context of the song or audio, the students are able to re-tell what the song or audio was about. Another benefit, the students are able to adjust the tone, dynamics, and to get used to the speed of delivery with the particular conversation they have in the future. According to Underwood (Underwood, 1989, as cited in Gilakjani \& Ahmadi, 2011), there are seven difficulties that English language learners face during listening learning activity. The first one is the students cannot control the speed of delivery. Second, students rarely practice their listening skill. Third, students have a limited vocabulary. Fourth, students are unable to recognize the signals of transition from one topic to another topic. Fifth, students have lack contextual knowledge. Sixth, students are difficult to concentrate in a foreign language. Seventh, students may have certain learning habits.

The fourth method is playing game, the students will have a game session per week, the game will focus on enriching students' vocabulary or practicing their speaking skill. There are some games usually played by the students. The tutors will guide the students during the game. Afterward, the tutor will give a reward to the student who gets highest score. The purpose of this method is to make the speaking class more casual and interactive yet still effective to improve speaking skill. The last method is singing, the students will be asked to sing an English song so the tutor can fix if there is a wrong pronunciation so the students will have a clear pronunciation and get used to English accent.

To improve children skills more effectively, Kampung Inggris Pontianak also monitors and reports the children improvement to their parents. It is hoped so parents could understand children improvement and trust their children to study at Kampung Inggris Pontianak. Reports are reported via WhatsApp group.

\section{Tutor Obstacles During Teaching Activity}

There are some obstacles faced by tutor. After got the information from the participant, the researcher divides the obstacles into two, external and internal factors. Internal factors mean that the obstacle or problem comes from the tutor. Meanwhile, external factor comes from students. 
Internal factors is most of the tutors are not from educational background. It makes them, sometimes, hard to control elementary school students which very energetic. They might be from English language background, however, it is not adequate to teach student compared to tutors from English educational background. Therefore, Kampung Inggris Pontianak holds micro-teaching to see how far tutor candidates can teach before they can come into a class.

External factor is often new students make many false answers on placement test just to make them get in a lower level class than they are supposed to be. It is because students do not feel confident with their skills. However, after few days of learning process, tutor is able to know how far the skills of the students and tutor will recommend the students to change the class based on their abilties.

\section{CONCLUSION}

Kampung Inggris Pontianak focuses English speaking skill to elementary school students which is separated into four levels, basic, intermediate 1, intermediate 2, and advanced. There are five methods given by Kampung Inggris Pontianak to improve students' English speaking skill. Fortunately, those five methods aim not only to improve their speaking skill, but also listening skill because both are two important skills need in communication. Tutors also face some obstacles during the class. It is because either they do not have adequate educational background or students, sometimes, do not feel confident to their skills. However, Kampung Inggris Pontianak also has a program namely sharing session to monitor and to together look for way out if tutor faces a problem. For further research, the researcher suggests to add the data of student difficulties during English speaking learning.

\section{REFERENCES}

Ahmadi, L.-M. L. \& S. M. (2017). An analysis of factors influencing learners' English speaking skill. International Journal of Research in English Education, 2(1), 3441.

Aryana, S., \& Apsari, Y. (2018). Analyzing Teacher's Difficulties in Teaching Listening. Eltin Journal, Journal Of English Language Teaching In Indonesia, $6(2), 100-106$.

Chaney, A. (1998). Teaching Oral Communication in Grades K-8. Viacom company.

Garg, S., \& G. (2015). Learning English Can Change Your Life for The Better. International Journal of English Language, Literature and Humanities, III(II).

Gilakjani, A., P. \& Ahmadi, M., R. (2011). A Study of Factors Affecting EFL Learners' English Listening Comprehension and The Strategies for Improvement. Journal of Language Teaching and Research, 2(5), 977-988.

Hornby, A. S. (2005). Oxford Advanced Learner's Dictionary. Oxford: Oxford University Press.

Kampung-inggris.com. (2019). Apakah Kampung Inggris Membuka Cabang. KampungInggris.Com. membuka-cabang/

https://www.kampung-inggris.com/apakah-kampung-inggris-

Muhsin, M. A. (2016). The Effectiveness of Positive Feedback in Teaching Speaking Skill. Lingua Cultura, 10(1), 25-30. https://doi.org/10.21512/lc.v10i1.873 
Satria, V.R. (2020). English Speaking Teaching Methods for Elementary School Student at Kampung Inggris Pontianak. Celtic: A Journal of Culture, English Language Teaching, Literature, \& Linguistics, 7(2), 183-190.

Nanda, K. A., Putri, T. S., Afifah, E. M., Nofianti, S. E., Agustin, I. P., \& Qudsyi, H. (2020). Pengaruh Metode Pembelajara n Flash Card Terhadap Keterampilan Berbicara Bahasa Inggris Pada Siswa Sekolah Dasar. Jurnal RAP (Riset Aktual Psikologi), 11(1), 15-23.

Nugroho, A. (2019). Reza Rahardian Kampanye di Kampung Inggris Terkait English for Indonesia. Radarkediri.Jawapos.Com. https://radarkediri.jawapos.com/read/2019/03/06/123368/reza-rahardiankampanye-di-kampung-inggris

Nurjaya. (2018). Belajar di Kampung Inggris Pare, Bukan Hanya Beda Daerah Tapi Bisa Berteman Dengan Beda Negara Juga Loh. Kampunginggris.Id. https://www.kampunginggris.id/belajar-di-kampung-inggris-pare

Panduan Kampung Inggris. (2019). Sejarah Berdirinya Kampung Inggris Pare di Kabupaten Kediri. Panduankampunginggris.Com. https://www.panduankampunginggris.com/sejarah-kampung-inggris-pare/

Ramadhani, W., \& Poedjiastutie, D. (2020). Academic Culture Barriers Faced by English Department Students Joining International Internship Program. Celtic: A Journal of Culture, English Language Teaching, Literature and Linguistics, 7(1).

Setyarini, S. (2010). Puppet Show": Inovasi Metode Pengajaran Bahasa Inggris Dalam Upaya Meningkatkan Kemampuan Berbicara Siswa SD. Jurnal Penelitian Pendidikan, 11(1).

Setyowati, L. (2019). Improvement of Speaking By Using Presentation In Cultivation Program Student of Politeknik Kelapa Sawit Bekasi. Journal of English Education, Linguistics and Literature, 5(2), 16-25.

Trisnadewi, K., \& Lestari, E. A. P. (2018). Pengaruh Language Games Terhadap Kemampuan Berbicara Bahasa Inggris. Kulturistik, Jurnal Bahasa \& Budaya, 2(1).

Wang, Z. (2015). An Analysis on the Use of Video Materials in College English Teaching in China. International Journal of English Language Teaching, 2(1). https://doi.org/10.5430/ijelt.v2n1p23

Warschauer, M. (2000). The Changing Global Economy and The Future of English Teaching. Tesol Quarterly, 34(3), 511-535.

Widowati, D. R., \& Kurniasih. (2018). Critical Reading Skill and Its Implication To Speaking Ability In Multicultural Classroom. Celtic: A Journal of Culture, English Language Teaching, Literature and Linguistics, 5(2), 18-23. 